\title{
FUTILITY OF THE REGULATORY FRAMEWORK ON THE ORGANIZATION AND OPERATION OF PUBLIC GATHERINGS - THE RIGHT TO PROTEST IN ROMANIA
}

\author{
M-A. ARVA
}

\section{Marius-Adrian ARVA}

Student Police Academy „Alexandru Ioan Cuza”, Faculty of Police

Mailing address: City of Iași, Poitiers Boulevard, no. 18-22, postal code 700671, Iași County

E-mail: arvamariusadrian@yahoo.com

\section{ABSTRACT:}

If in the introductory part of the paper we present the constituent elements of the right to protest in relation to constitutional or conventional provisions and by analyzing some jurisprudential elements of the national courts and of the European Court of Human Rights, in the second part we carry out a detailed analysis of the solutions pronounced by the relevant national courts, based on which we concluded the uselessness of the sanctions regulation regarding the participation in protest actions carried out in a peaceful context.

KEY WORDS: freedom of expression, freedom of assembly, right to protest, jurisprudence.

\section{INTRODUCTION}

The recent events in the Romanian society's history regarding considerable assemblies of people, resulting in a strong civic awareness compels the institutional actors involved in ensuring the orderly climate in the public space to show an increased interest in the legislative framework by which they act, overcoming in the end the security of each individual.

However, it is imperative that there is a balance between guaranteeing by the state a favorable environment for the exercise of fundamental rights and freedoms and their justified limitation, meaning that (...) state authorities are obliged to take not only reasonable measures, but both firm and adequate ones, in order to ensure the peaceful conduct of lawful manifestations of its citizens and to oversee the public order keeping (... $)^{1}$.

We underscore that the chosen topic is of high interest in relation to the section concerned in the conference, given that by presenting the values put into debate by the national courts, we carry out a detailed analysis of the normative framework in which citizens exercise some of their basic constitutional rights that sparkled the public attention of the contemporary Romanian society, more precisely the right of freedom of expression and assembly.

Moreover, we advocate in the study conducted for the reconfirmation of these rights, carrying out a thorough study of the solutions given by the national judicial forums in relation to the exercise of these rights, in antithesis to the coercive attribute of the state authority.

Civil Decision no. 732/23.05.2018 of the Suceava Tribunal, available at www.rolii.ro, accessed on 22.11.2019. 


\section{DECODING THE RIGHT TO PROTEST}

As far as the right to protest of citizens, this can be understood as a merger of the constitutional provisions that consecrate the freedom of expression and the freedom of assembly.

According to article 30 paragraph (1) of the Romanian Constitution ${ }^{2}$, The freedom of expression of thoughts, opinions or beliefs and the freedom of creations of any kind, verbally, in writing, through images, sounds or other means of public communication are inviolable, but to these freedoms, the constitutional text opposes a series of restrictions by paragraph (6) and (7) of the same article, according to which Freedom of expression cannot harm the dignity, honor, private life of the person nor the right to one's own image, as well as They are forbidden the defamation of the country and the nation, the urge to wage war, to national, racial, class or religious hatred, incitement to discrimination, territorial separatism or public violence, as well as obscene manifestations, contrary to good morals, in other words, the right to free expression (...) is not an absolute one but it has some limitations, especially when they are needed to protect: the rights or reputation of others, public order, public healt or morals ${ }^{3}$.

In this respect, it arouses interest the solution of the court in which the constitutional and conventional limits of the right to free expression are argued, noting that the action of posting on the personal Facebook page expressions of insult respectively "slave" and "clipped pansy" to an identified gendarme through a photograph in the military outfit, (...) meets the constitutive elements of the contravention provided by article 2 point 1 of Law no. 61/1991, in the manner of publicly expressing offensive phrases against people, which could damage the dignity and honor of theirs or of public institutions ${ }^{4}$.

Therefore, as regards the right to free expression, according to the provisions of article 11 paragraph (2) of the Constitution, the national law must also be interpreted by reference to the European Convention on Human Rights ${ }^{5}$, meaning in which we show that according to article 10 of the Convention, 1. Everyone has the right to freedom of expression. This right shall include freedom to hold opinions and to receive and impart information and ideas without interference by public authority (...) 2. The exercise of these freedoms (...) may be subject to such formalities, conditions, restrictions or penalties as are prescribed by law (...).

Subject to these provisions, even if freedom of expression applies not only to information or ideas considered harmless, but also to those who shock or upset the state or any segment of the population ${ }^{6}$, the citizens benefiting from the right to express their dissatisfaction in a virulent and plastic way ${ }^{7}$, the interference with the exercise of their right to free expression pursues a legitimate purpose, the sanctioning norm (article 2 point 1 of Law no. 61/1991) being unable to affect the freedom of expression of the persons ${ }^{8}$, also keeping in

\footnotetext{
${ }^{2}$ Republished in the Official Monitor no. 767/31.10.2003.

${ }^{3}$ Civil sentence no. 8548/21.06.2017 of the Iasi Court, available at www.rolii.ro, accessed on 22.11.2019.

${ }^{4}$ Civil sentence no. 4538/03.05.2019 of the District 3 of Bucharest Court, available at www.rolii.ro, accessed on 22.11.2019.

${ }^{5}$ Law no. 30/1994 concerning the ratification of the Convention for the Protection of Human Rights and Fundamental Freedoms, published in the Official Monitor. no. 135/31.05.1994.

${ }^{6}$ Paragraph 32 of the ECHR Decision of Papaianopol against Romania from 16.03.2010, available at hudoc.echr.coe.int/eng $? i=001-123207$, accessed on 22.11.2019.

7 Civil Decision no. 3845/14.10.2019 of the Bucharest Tribunal, available at www.rolii.ro, accessed on 22.11.2019.

${ }^{8}$ Romanian Constitutional Court's Decision no. 476/10.05.2012, published in the Official Monitor no. 465/10.05.2012.
} 
FUTILITY OF THE REGULATORY FRAMEWORK ON THE ORGANIZATION AND OPERATION OF PUBLIC GATHERINGS - THE RIGHT TO PROTEST IN ROMANIA

mind that the acts sanctioned in this case are not actions against people, but against norms of social coexistence, against public order and peace ${ }^{9}$.

Thus, it will enjoy the protection offered by art. 10 of the Convention an opinion which is not totally devoid of a factual basis or a logical argumentation and is not expressed in insulting terms ${ }^{10}$, but a value judgment can prove excessive if it is totally devoid of factual basis $^{11}$, for which, it appears on fully justified the sanctioning of the petitioner in the case presented, for the use of expressions containing exclusively insulting terms.

Turning our attention to the constitutional context of the right to protest, we also emphasize that according to art. 39 of the Constitution, Rallies, demonstrations, processions or any other gatherings are open, but they can be organized and carried out only peacefully, without any weapons.

In relation to such interference with the rights of citizens, the constitutional forum has ruled that the exercise of the freedom of assembly may involve certain restrictions and conditions, according to the law, precisely because the rights and freedoms guaranteed by the Constitution to citizens, their interests and, implicitly, to public order and national security should not be affected ${ }^{12}$, such restrictions and conditions being imposed in order to protect the fundamental rights of other members from society, who do not participate in the respective gatherings (...) thus preventing disorder and maintaining order in traffic (... $)^{13}$.

Likewise, the case law of the European Court of Human Rights highlights the state's attribute to take reasonable and adequate measures to ensure the peaceful conduct of lawful manifestations of its own citizens ${ }^{14}$, even when the message transmitted by protesters irritates or disturbs other people who have opinions and claims contrary to their own promoted through the envisaged public demonstration ${ }^{15}$.

It is worth mentioning the essential role of freedom of expression as a precondition for a functional democracy, meaning that the effective exercise of the rights deriving from it does not only require the task of the states not to intervene, but may involve the undertaking of positive activities by the state authority for the protection of those involved ${ }^{16}$, being necessary to establish a balance between the general interest of the community and the individual one ${ }^{17}$.

\footnotetext{
9 Romanian Constitutional Court's Decision no. 74/07.03.2002, published in the Official Monitor no. 283/26.04.2002.

10 Paragraph 109 of the ECHR Decision of Grivna Newspaper Redaction against Ukraine, available at hudoc.echr.coe.int/eng? $i=001-192461$, accessed on 22.11.2019.

${ }^{11}$ Paragraph 59 of the ECHR Decision of Niculescu-Dellakeza against Romania of 26.03.2013, available at hudoc.echr.coe.int/eng? $i=001-176285$, accessed on 22.11.2019.

12 Romanian Constitutional Court's Decision no. 199/23.11.1999, published in the Official Monitor no. 76/21.02.2000.

${ }^{13}$ Paragraph 19 of Romanian Constitutional Court's Decision no. 687/24.11.2016, published in the Official Monitor no. 137/23.02.2017.

${ }^{14}$ Paragraph 34 of the ECHR Decision of Plattform "ÄRZTE FÜR DAS LEBEN" against Austria, available at hudoc.echr.coe.int/eng? $i=001-57558$, accessed on 22.11.2019.

${ }^{15}$ Paragraph 86, 2nd thesis of the ECHR Decision of Stankov and the United Macedonian Organization Ilinden against Bulgaria, available at hudoc.echr.coe.int/eng? $i=001-59689$, accessed on 22.11.2019.

16 Paragraph 23 of the ECHR Decision of $\mathrm{X}$ and $\mathrm{Y}$ against the Netherlands, available at hudoc.echr.coe.int/eng? $i=001-57603$, accessed on 22.11.2019.

17 Paragraph 43 of the ECHR Decision of Özgür Gündem against Turkey, available at hudoc.echr.coe.int/eng? $i=001-58508$, accessed on 22.11.2019.
} 


\section{Marius-Adrian Arva}

Making a mixture of the two concepts, the special law in this matter ${ }^{18}$ establishes the limits in which public gatherings can take place in public premises, respectively only after a prior declaration ${ }^{19}$, conditioned by the unfolding without disturbing the normal use of public roads, public transport, except for authorized ones, the functioning of public or private institutions, those of education, culture and health, economic units or by degenerating into turbulent actions that endanger the public order and the public peace, the safety of persons, their physical integrity, life and their goods or of the public domain, and cannot be continued after 23.00 hours $^{20}$.

\section{JURISPRUDENTIAL EXAMINATION ON THE RIGHT TO PROTEST}

A first problem of interest on the restrictions that the state can impose on its citizens with reference to their right to protest is the obligation to declare such a manifestation, meaning that the legislator lists the exceptional situations that derive from this obligation, in the sense that it should not previously declared public meetings (...) that are held outside or inside the premises or buildings of legal persons of public or private interest ${ }^{21}$, constituting contraventional acts the organization and conduct of undeclared, unregistered or prohibited public meetings ${ }^{22}$, as well as participation to undeclared or banned public gatherings $(\ldots)^{23}$.

Considering these legal limitations as a violation of the constitutional freedoms, establishing a real obstacle in organizing peaceful public demonstrations ${ }^{24}$, within the legislative approach, it was submitted a motion proposal for amending article 3 of Law no.60/1991, which intended to supplement the list of exceptions regarding the prior declaration of public demonstrations also for political protests, as well as those taking place in public squares ${ }^{25}$.

With respect to the legislative initiative envisaged, the Chamber of Deputies Committee for Defense, Public Order and National Security submits the report rejecting the proposal, reasoning that the rule of prior declaration of public gatherings would thus become an exception, which may burden the $\mathrm{law}^{26}$, considering the rulings of the Romanian Constitutional Court, according to which the rule of their declaration does not contravene the constitutional and conventional freedom of assembly ${ }^{27}$, as well as the solution given by the Romanian Supreme Court vested with the settlement of an appeal in the interest of law, by which it was stated that (...) if a public gathering is held outside the premises or buildings of legal entities of public or private interest, and this exterior coincides, overlapping with one of the places mentioned in article 1 paragraph (2) of Law no. 60/1991 (markets, public roads or

\footnotetext{
${ }^{18}$ Law no. 60/1991 regarding the organization and conduct of public gatherings, republished in the Official Monitor no. 186/14.03.2014.

19 article 1 paragraph (2) of Law no. 60/1991.

${ }^{20}$ article 2 of Law no. 60/1991.

${ }^{21}$ article 3 of Law no. 60/1991.

${ }^{22}$ article 26 paragraph (1) letter a) of Law no. 60/1991.

${ }^{23}$ article 26 paragraph (1) letter d) of Law no. 60/1991.

24 Reason for the Legislative Proposal to amend article 3 of Law no.60/1991, available at www.cdep.ro/pls/proiecte/upl_pck2015. project? cam $=2 \&$ idp $=17399$, accessed on 22.11.2019.

${ }^{25}$ The legislative proposal for the alteration of article 3 of Law 60/1991 regarding the organization and conduct of public gathering, available at www.cdep.ro/pls/proiecte/upl_pck2015.proiect?cam $=2 \& i d p=17399$, accessed on 01.11 .2019 .

${ }^{26}$ Report on the legislative proposal for the modification of article 3 of Law no. 60/1991, p. 2, available at www.cdep.ro/pls/proiecte/upl_pck2015.proiect? cam $=2 \& i d p=17399$, consulted on 22.11.2019.

${ }^{27}$ Paragraph 19 of Romanian Constitutional Court's Decision no. 687/24.11.2016.
} 
FUTILITY OF THE REGULATORY FRAMEWORK ON THE ORGANIZATION AND OPERATION OF PUBLIC GATHERINGS - THE RIGHT TO PROTEST IN ROMANIA

other outdoor places, red.), the rule establishing the obligation to prior declare the public gathering becomes applicable $e^{28}$.

Through the solution thus pronounced, the Supreme Court makes a dissonant note with regard to the ordinary courts' majority orientation invested with casuistry on sanctioning misdemeanors according to article 26 paragraph (1) letter a) and d) of Law no. 60/1991 prior to the ruling of the supreme court, according to which the public meetings held in a public place outside the premises of legal entities should not be declared ${ }^{29}$, by reference to the exemption from the obligation of prior declaration of public gatherings established by article 3 of Law no. 60/1991.

Thus, finding that (...) if it was considered that no prior declaration was necessary (...), there would be a risk that the public authorities vested with ensuring the public order of the gathering could not fulfill these duties ${ }^{30}$, the supreme court lends itself to the minority opinion outlined on this subject, according to which if we accept the thesis that sidewalks and the driveway, elements of a public communication route disposed in the proximity of a public institution, could be considered as belonging to the outside of its headquarters, (...) this means that no manifestation should be declared, practically emptying the content of the legal regulation, because any public space is outside the headquarters of an institution ${ }^{31}$, therefore the exception established by article 3 of Law no. 60/1991 continuing to operate only for (...) the area between the access points in the building (representing the headquarters/building of the legal entitz, red.) and its fence (... $)^{32}$.

If on this issue, according to article 517 paragraph (4) of the Code of Civil Procedure, the solution given by the supreme court becomes imperative, the debate remains on the problem of incriminating the participation to undeclared or forbidden public protest gatherings, given that it became a notoriety factor of the Romanian society's recent years, the high number of protesters who actively participate in such public gatherings, organized most of the times in the vicinity of legal entities headquarters (town halls, political parties, central authorities, etc.).

In relation to the provisions of article 26 paragraph (1) letter a) of Law no. 60/1991, the competent authorities have the capacity to identify and sanction a person or an organizing group of such a protest gathering undeclared, unregistered or prohibited, but compared to the deed of participating to protests under the conditions of article 26 paragraph (1) letter d) of Law no. 60/1991, we point out the inequity, as well as the material and operational inability of the public authorities to identify and sanction a considerable number of protesters, which in some cases can reach as high as tens of thousands of participants ${ }^{33}$.

\footnotetext{
${ }^{28}$ Concluclusion of the Supreme Court's Decision no. 19/15.10.2018, published in the Official Monitor no. $1055 / 13.12 .2018$.

${ }^{29}$ Final paragraph, page 2 of the Bucharest Court of Appeals Address no. 6/1784/C of 02.07.2018 for the notification of the Supreme Court on an appeal in the interest of law, available at www.scj.ro/CMS/0/PublicMedia/ GetIncludedFile? id=20047, accessed on 22.11.2019.

${ }^{30}$ Paragraph 93 of the Supreme Court's Reasonings no. 19/2018.

31 Civil Decision no. 3993/17.09.2018 of the Bucharest Tribunal, available at www.rolii.ro, accessed on 22.11.2019.

${ }^{32}$ Civil Decision no. 2048/05.04.2017 of the the Bucharest Tribunal, available at www.rolii.ro, accessed on 22.11.2019.

${ }^{33}$ For example, the peaceful protest that took place on the evening of 31.01.2017 on Victory Square in Bucharest, where about 20.000 protesters attended, according to the Minister of Internal Affairs press release from 02.02.2017, available at www.mai.gov.ro/declaratie-de-presa-a-ministrului-afacerilor-interne-carmendaniela-dan/, consulted on 22.11.2019.
} 


\section{Marius-Adrian Arva}

Therewith, observing the jurisprudential orientation on recognizing the legitimacy of undeclared, peaceful, small-scale protests, in which a limited number of persons participate, either by canceling the sanctioning act $^{34}$, or by noting the need to replace the fine with a "warning" in relation to the given circumstances (the gathering to which the petitioner participated was a peaceful one, unsold with major disturbance of institutions' activity in the area or of car and pedestrian traffic, thus not producing a very dangerous situation ${ }^{35}$ ), we point out the inefficiency of such a sanctioning norm for the activity of taking part into a protest.

\section{CONCLUSIONS}

Thus, in relation to European principles set out in the incipient part, as well as the ordinary courts' orientation regarding the solutions pronounced in accordance with constitutional provisions, we stress out the necessity of the legislator's intervention in order to expressly abrogate the provisions of article 26 paragraph (1) letter d) of Law no. 60/1991.

Such a solution must also be considered by taking into account the hypotheses in which disturbing elements of protest manifestations may arise, either by instigating or resorting to acts of violence, or by other antisocial activities, law enforcement agencies having sufficient sanctioning instruments (article 26 paragraph (1) letter e) and i) of Law no. 60/1991, the Penal Code and the Code of Criminal Procedure) for solving specific situations as the ones described above.

\section{BIBLIOGRAPHY:}

Romanian Constitution, republished in the Official Monitor no. 767/31.10.2003.

Law no. 60/1991 regarding the organization and conduct of public gatherings, republished in the Official Monitor no. 186/14.03.2014.

Law no. 30/1994 concerning the ratification of the Convention for the Protection of Human Rights and Fundamental Freedoms, published in the Official Monitor. no. 135/31.05.1994.

The Bucharest Court of Appeals Address no. 6/1784/C of 02.07.2018 for the notification of the Supreme Court on an appeal in the interest of law, www.scj.ro.

Report on the legislative proposal for the modification of article 3 of Law no. 60/1991, www.cdep.ro/pls/proiecte/upl_pck2015. proiect? cam $=2 \& i d p=17399$.

The legislative proposal for the alteration of article 3 of Law 60/1991, www.cdep.ro/pls/proiecte/upl_pck2015.proiect? cam=2\&idp=17399.

The Minister of Internal Affairs press release from 02.02.2017, www.mai.gov.ro.

Reason for the Legislative Proposal to amend article 3 of Law no.60/1991, www.cdep.ro/pls/proiecte/upl_pck2015. proiect? cam $=2 \& i d p=17399$.

ECHR Decision Niculescu-Dellakeza against Romania, hudoc.echr.coe.int/eng?i=001-176285.

ECHR Decision Özgür Gündem against Turkey, hudoc.echr.coe.int/eng?i=001-58508.

ECHR Decision Papaianopol against Romania, hudoc.echr.coe.int/eng?i=001-123207.

ECHR Decision Plattform „ÄRZTE FÜR DAS LEBEN” against Austria, hudoc.echr.coe.int/eng? $i=001-57558$.

ECHR Decision Grivna Newspaper Redaction against Ukraine, hudoc.echr.coe.int/ eng?i=001192461.

\footnotetext{
${ }^{34}$ Civil Decision no. 2839/02.09.2019 of the Bucharest Tribunal, available at www.rolii.ro, accessed on 22.11.2019 (see also civil decision no. 2322/03.06.2019 and civil decision no. 2955/09.09.2019 of the Bucharest Tribunal).

35 Civil Decision no. 2381/05.06.2019 of the Bucharest Tribunal, available at www.rolii.ro, accessed on 22.11.2019 (see also civil decision no. 1780/16.04.2019 of the Ilfov Tribunal).
} 
FUTILITY OF THE REGULATORY FRAMEWORK ON THE ORGANIZATION AND

OPERATION OF PUBLIC GATHERINGS - THE RIGHT TO PROTEST IN ROMANIA

ECHR Decision Stankov and the United Macedonian Organization Ilinden against Bulgaria, hudoc.echr.coe.int/eng? $i=001-59689$.

ECHR Decision X and Y against Holland, hudoc.echr.coe.int/eng? $i=001-57603$.

RCC's Decision no. 199/23.11.1999, published in the Official Monitor no. 76/21.02.2000.

RCC's Decision no. 74/07.03.2002, published in the Official Monitor no. 283/26.04.2002.

RCC's Decision no. 476/10.05.2012, published in the Official Monitor no. 465/10.05.2012.

RCC's Decision no. 687/24.11.2016, published in the Official Monitor no. 137/23.02.2017.

RSC's Decision no. 19/15.10.2018, published in the Official Monitor no. 1055/13.12.2018.

Civil Decision no. 2048/05.04.2017 of the the Bucharest Tribunal, www.rolii.ro.

Civil Decision no. 732/23.05.2018 of the Suceava Tribunal, www.rolii.ro.

Civil Decision no. 3993/17.09.2018 of the Bucharest Tribunal, www.rolii.ro.

Civil Decision no. 2381/05.06.2019 of the Bucharest Tribunal, www.rolii.ro.

Civil Decision no. 2839/02.09.2019 of the Bucharest Tribunal, www.rolii.ro.

Civil Decision no. 3845/14.10.2019 of the Bucharest Tribunal, www.rolii.ro.

Civil Sentence no. 4538/03.05.2019 of the District 3 of Bucharest Court, www.rolii.ro. 